\title{
2003 年 8 月沙流川洪水時の \\ 二風谷ダム湖内の土砂移動 \\ SEDIMENT TRANSPORT IN THE NIBUTANI DAM RESERVOIR AT 2003 FLOOD LF THE SARU RIVER
}

\author{
島田友典 ${ }^{1} \cdot$ 吉川泰弘 $^{2} \cdot$ 渡邊康玄 $^{3}$ \\ Tomonori Shimada and Yasuhiro Yosikawa and Yasuharu Watanabe \\ 1正会員 独立行政法人 北海道開発土木研究所 ( $\bar{T} 062-8602$ 札幌市豊平区平岸 1 条 3 丁目)
2正会 独立行政法人 北海道開発土木研究所 ( $\bar{T} 062-8602$ 札幌市豊平区平岸 1 条 3 丁目)
3正会 工博 独立行政法人 北海道開発土木研究所 ( $\bar{T} 062-8602$ 札幌市豊平区平岸 1 条 3 丁目)
}

Sedimentation in dam reservoirs is a serious matter of great concern with river management works.In general,sediment deposited in the reservoir is hard to move comparing with river bed materials,even if the diamete is equal.Therefore,hydraulic experiments were conducted on the fall velocity of sediment and the entrainment rate of suspended sediment using the material which is deposited in the dam reservoir.It is found that the fall velocity of sediment and the entrainment rate of suspended sediment are smallre then the value currently used conventionally. These results are applied to calculate bed variation of the 2003 flood in the Nibutani Dam resevoir.The calculated results mostly agree with field surveys.

Key Words : Saru River, Nibutani dam, reservoir, fall velocity of aediment, entrainment rate of suspended sediment

\section{1. はじめに}

近年河道内における土砂の侵食・堆砂作用に伴う洪 水流下能力の変化, 上・下流に扔ける土砂収支のアン バランス等の課題が指摘され，河川管理において流域 一貫した土砂管理の重要性が指摘されている．河川に おいて土粒子の移動は特に増水時に顕著に生じ, 下流 域へと供給されることから, 各地に扔いて洪水時の物 質輸送に関する現地調査が実施されてきている.

北海道開発土木研究所では，中流域にダム湖の存在 する北海道の一級河川である沙流川において洪水時の 調査を実施し, 中下流域の SS や栄養塩類の挙動につい て把握を行ってきて扔り, 出水時の観測データ・出水前 後の横断測量等を用いた土砂収支について良好な結果 を得ている. 1)2)3)

沙流川中流域に位置する二風谷ダム (図-1)には，年 間 100 万 $\mathrm{m}^{3}$ の土砂が堆積しており, 維持上の問題と もなり得る. 特に 2003 年 8 月に生起した台風 10 号に よる洪水では, 既往最大流量を記録し，ダム湖にも 240 万 $\mathrm{m}^{3}$ の土砂が堆積した.

本論文では，現在まで沙流川での洪水観測により蓄 積されたデータをもとに，中流域にダム湖の存在する 流域一貫を対象とした土砂収支の予測を行っていく第
一歩として, 未解明部分の多いダム湖内に堆積する粒 径の非常に細かい土粒子の挙動を把握することを目的 に, 二風谷名湖の底質採取，採水した試料を用いて 土粒子の沈降・浮上実験を行い，二風谷ダム湖内にお ける沈降・浮上の推定式を導き出すこととした．さら にこの結果を利用し，2003 年 8 月に起こった沙流川で の出水時のダム湖内に打ける現象を再現することを試 みた。

\section{2. 土粒子の沈降・浮上実験}

ダムに堆積した細粒径の粘着性土粒子の挙動を明確 にするため, 二風谷ダムに 2003 年 8 月洪水でダム湖底 に堆積した土砂を出来る限り不覚乱状態で採取し, 土 粒子の沈降・浮上実験を実施した。 その結果を用いて 土粒子の沈降速度及び浮上速度について, 河床変動計 算で用いられている砂磁を対象とした既往の式の適応 性について明らかにすることとした。

\section{(1) 沈降実験}

\section{a) 沈降実験の概要}

使用した実験装置を図-2に示す．採取した底質材料 を $75 \mu \mathrm{m}$ メッシュのふるいにかけ実験用の試料をつく り, 画像解析装置により 1 回あたり 150 個の粒径ごと 


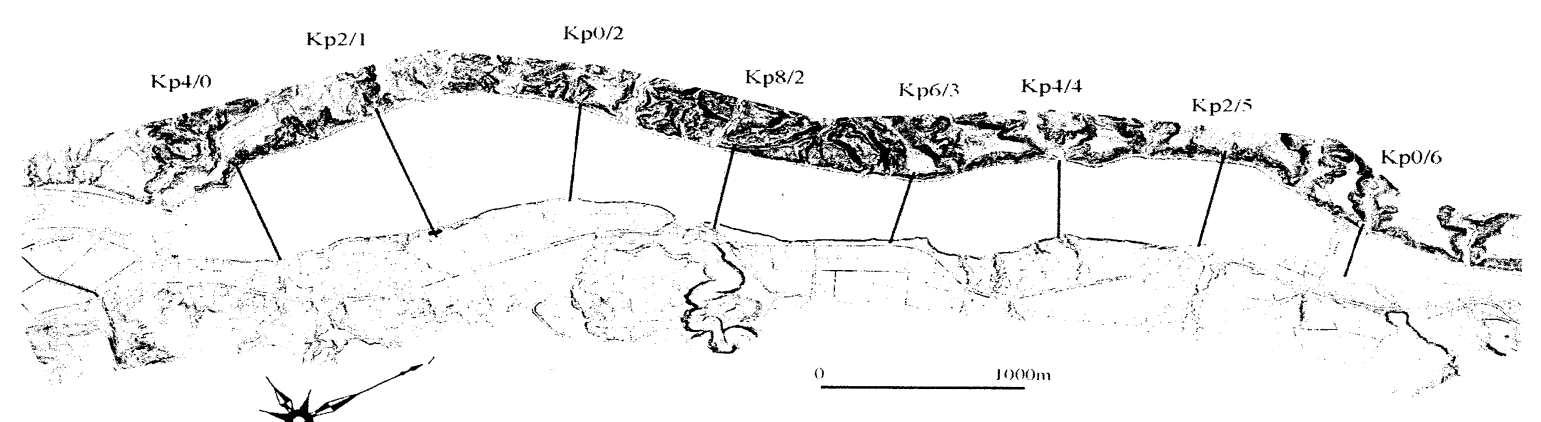

図-1 二風谷ダム湖

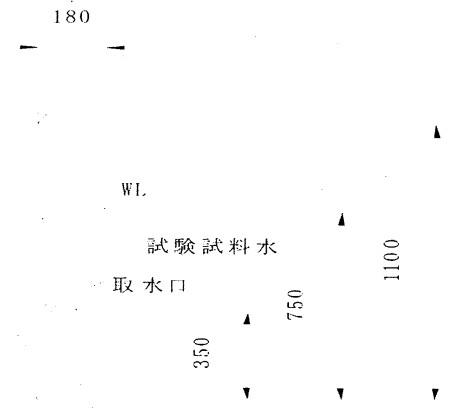

図-2 沈降実験に用いた実験装置

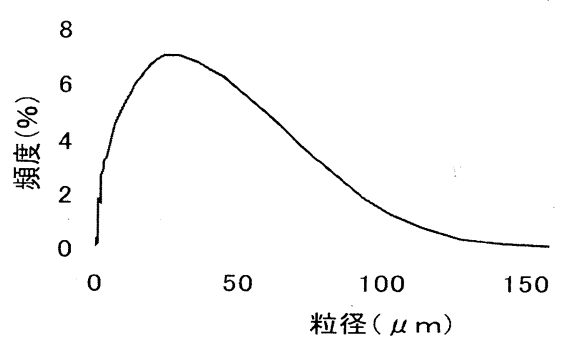

図-3 ふるい分け後の通過頻度

の沈降速度を測定しこれを 5 回実施した。 なお、子る いにかけた後の通過頻度は図-3のとおりである.

\section{b) 沈降実験の結果}

実験の結果を図-4 に示す．比較のため沈降速度式と して一般に用いられている (1) 式で表される Rubey の 式もあわせてプロットする.

$\begin{cases}w_{f i}=\left(\sqrt{\frac{2}{3}+\frac{36 \nu^{2}}{s g d_{i}^{3}}}-\sqrt{\frac{36 \nu^{2}}{s g d_{i}^{3}}}\right) \sqrt{s g d_{i}} & : d_{i} \leq 0.1 \mathrm{~cm} \\ w_{f i}=32.8 d_{i}^{\frac{1}{2}} & : d_{i}>0.1 \mathrm{~cm}\end{cases}$

ここで, $w_{f i}$ : 沈降速度, $\nu$ :水動粘性係数， $s$ :砂粒の水中 比重, $d_{i}$ :砂粒の粒径 (下添字 $i$ は混合粒径における粒径 $d_{i}$ の粒子に対する物理量を表す。以下全てに共通), $g$ : 重量加速度である.

Rubey の沈降速度式と実験結果を比較すると，全体 的に実験值が小さいことが確認された。この結果を受 けて, 二風谷ダム湖内に堆積した土砂の沈降速度式を 導くことにした. 図-4より最小二乗法により線形近似 を行い，(2) 式を得た. ただし今回の実験では粒径の細

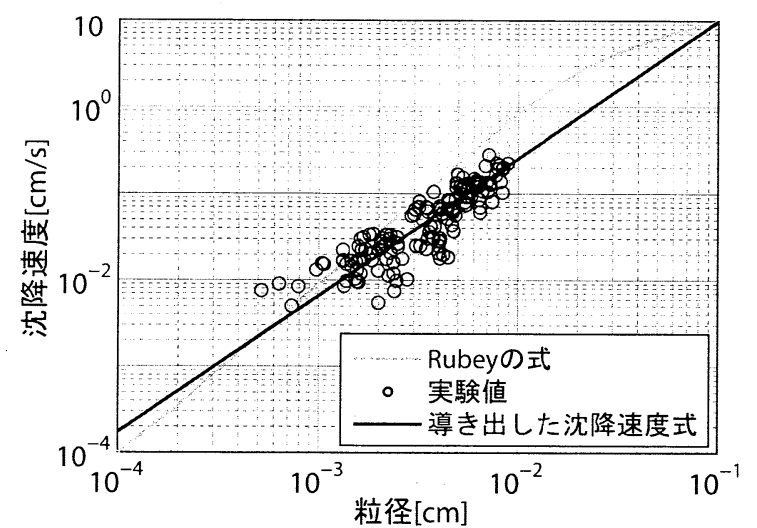

図-4 沈降速度実験結果

かいもののみで実験を行ったため, (2) 式の適用範囲は $d_{i} \leq 0.1 \mathrm{~cm}$ である.

$$
n w_{f i}=376.5 d_{i}^{1.58}
$$

\section{（2）浮上実験}

\section{a) 浮上実験の概要}

北海道開発土木研究所が所有する延長 $25.0 \mathrm{~m}$, 幅 1.0III，深さ $1.0 \mathrm{~m}$ の可傾斜水路を用いて二風谷ダム湖 で採取した試料を用いて実験を行った。使用した実験 水路は図-5に示すとおりで，上流から $11.0 \mathrm{~m} \sim 15.0 \mathrm{~m}$ の区間 (長さ $4.0 \mathrm{~m}$ ・幅 $1.0 \mathrm{~m}$ ) にダム湖の底質を敷き詰 め，表-1 の条件で 30 分間の通水を行った.

底質区間の河床高測定は縦断方向に左右岸それぞれ 9 点とし, 通水開始時および 5 分毎の計 7 回計測を行った.

（1） また底質材料の移動量を求めるため, 通水前後にお いて詳細な河床高の測定を行った. 計測数は横断方向 5 点と縦断方向 9 点である．この結果より底質材料区間に おける通水前後の底質材料の実体積を算出し, その差 を移動量とした．併せて底質材料の粒度分析も行った。

さらに浮遊砂濃度測定のため通水中に水路内の 1 点 で採水を行った. 計測数は通水前と 10 分毎の計 4 回で ある. 併せて浮遊砂の粒度分析も行った.

\section{b) 浮上実験の結果}

通水前後の河床高の左右岸平均值を図-6に，底質材 料の移動量を表-2 に, 水中の SS 濃度を表-3に示す. 


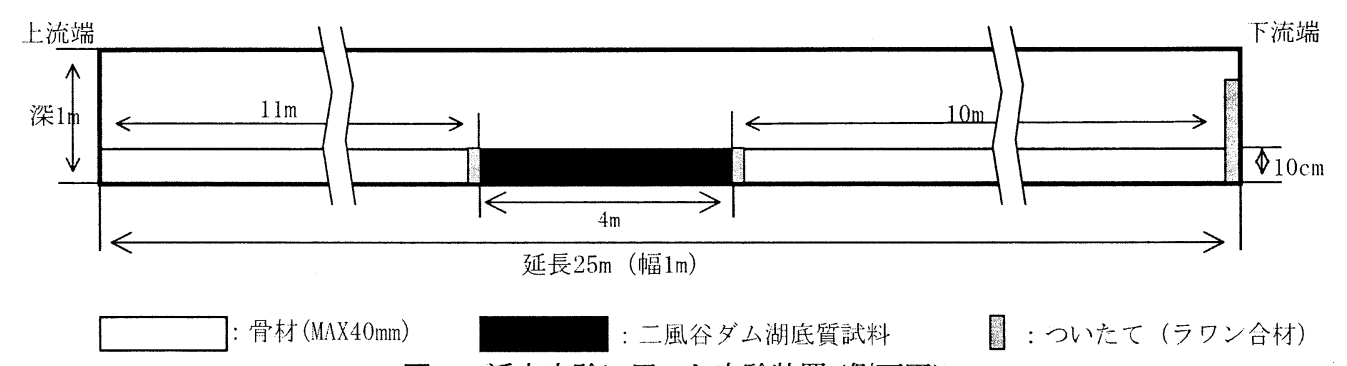

図-5 浮上実験に用いた実験装置 (側面図)

表-1 浮上実験の諸元

\begin{tabular}{|c|c|c|c|}
\hline & ケース 1 & ケース 2 & ケース 3 \\
\hline 流量 $\left(\mathrm{m}^{3} / \mathrm{s}\right)$ & 0.10 & 0.20 & 0.22 \\
\hline 河床勾配 & $1 / 5000$ & $1 / 5000$ & $1 / 400$ \\
\hline 水深 $(\mathrm{cm})$ & 75 & 55 & 21 \\
\hline 通水時間 $($ 分 $)$ & 30 & 30 & 30 \\
\hline
\end{tabular}
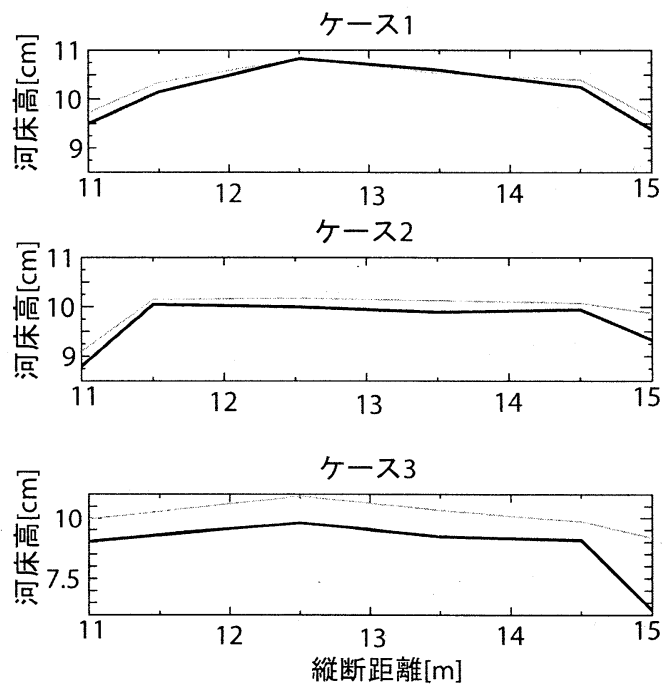

通水前 — 通水後

図-6 河床高変化

表-2 通水後の底質材料移動量

\begin{tabular}{|c|c|c|c|}
\hline & 投入量 $\left[\mathrm{m}^{3}\right]$ & 残留量 $\left[\mathrm{m}^{3}\right]$ & 移動量 $\left[\mathrm{m}^{3}\right]$ \\
\hline ケース 1 & 0.399 & 0.378 & 0.022 \\
\hline ケース 2 & 0.383 & 0.358 & 0.025 \\
\hline ケース 3 & 0.412 & 0.257 & 0.154 \\
\hline
\end{tabular}

これらの結果より実験で計測された浮上量を算出し た. 算出方法は (3) 式を用いた。

$$
\frac{\partial z}{\partial t}=\frac{1}{1-\lambda}\left(q_{s u i}-n w_{f i} \times c_{i}\right)
$$

ここで $q_{s u i}$ :粒径別単位時間単位面積あたりの河床から の浮上量, $z$ : 河床高, $t$ : 時間, $\lambda$ : 空隙率, $c_{i}$ : 粒径別浮遊
表-3 通水前後における SS 濃度

\begin{tabular}{|c|c|c|}
\hline & 通水前 $\mathrm{SS}(\mathrm{mg} / \mathrm{l})$ & 通水後 $\mathrm{SS}(\mathrm{mg} / \mathrm{l})$ \\
\hline ケース 1 & 17.00 & 18.50 \\
\hline ケース 2 & 19.50 & 31.30 \\
\hline ケース 3 & 277.75 & 335.00 \\
\hline
\end{tabular}

砂濃度である.

なお比較のため，(4) 式で表される板倉の式4)5)を用 いた浮上量を算出するこことした．板倉の式は粘着性 土を対象としないが，沙流川の河床変動計算6)において 採用され，実測を精度よく再現していることから，本 研究で対象とする非常に細かい土粒子にも適用可能か を見るために採用した。

$$
q_{s u i}=p_{i} K\left(\alpha_{*} \frac{\rho_{s}-\rho}{\rho_{s}} \frac{g d_{i}}{u_{*}^{\prime}} \Omega_{i}-w_{f i}\right)
$$

ここで, $p_{i}$ : 粒径 $d_{i}$ の粒子が存在する割合, $\rho_{s}$ : 浮遊砂 粒子の密度, $\rho$ :水の密度, $u_{*}^{\prime}$ : 有効摩擦速度, $K=0.008$, $\alpha_{*}=0.14$ である. また $\Omega_{i}$ は (5) 式で表される.

$$
\Omega_{i}=\frac{\tau_{* i}^{\prime}}{B_{* i}} \frac{\int_{a^{\prime}}^{\infty} \xi \frac{1}{\pi}\left(-\xi^{2}\right) d \xi}{\int_{a^{\prime}}^{\infty} \frac{1}{\pi}\left(-\xi^{2}\right) d \xi}+\frac{\tau_{* i}^{\prime}}{B_{* i} \eta_{0}}-1
$$

ここで $\tau_{* i}^{\prime}:$ 粒径別限界無次元有効掃流力, $\eta_{0}=0.5, B_{* i}$ : 揚力算定の際の速度に摩擦速度を適用するための換算 係数であり, 均一粒径の場合は $B_{* i}=0.143$ の一定值が 用いられるが混合粒径では (6) 式が用いられる.

$$
B_{* i}=\xi_{i} B_{* 0}
$$

ここで $\xi_{i}=\tau_{* c i} / \tau_{* c i 0}, \tau_{* c i}$ : 粒径別無次元掃粒力, $\tau_{* c i 0}$ : 単一粒径に対する限界摩擦速度, $B_{* 0}=0.143$ である. ま た (5) 式の $a^{\prime}$ は (7) 式が用いられる.

$$
a^{\prime}=B_{* i} \frac{B_{* i}}{\tau_{* i}}-\frac{1}{\eta_{0}}
$$

ここで $\tau_{* i}$ : 粒径別無次元掃流力である. なお (4) 式と (5) 式の $u_{*}^{\prime}$ と $\tau_{* i}^{\prime}$ は本来は全せん断力から河床波等の形状 抵抗成分をのぞいた成分とするべきものであるが，こ 

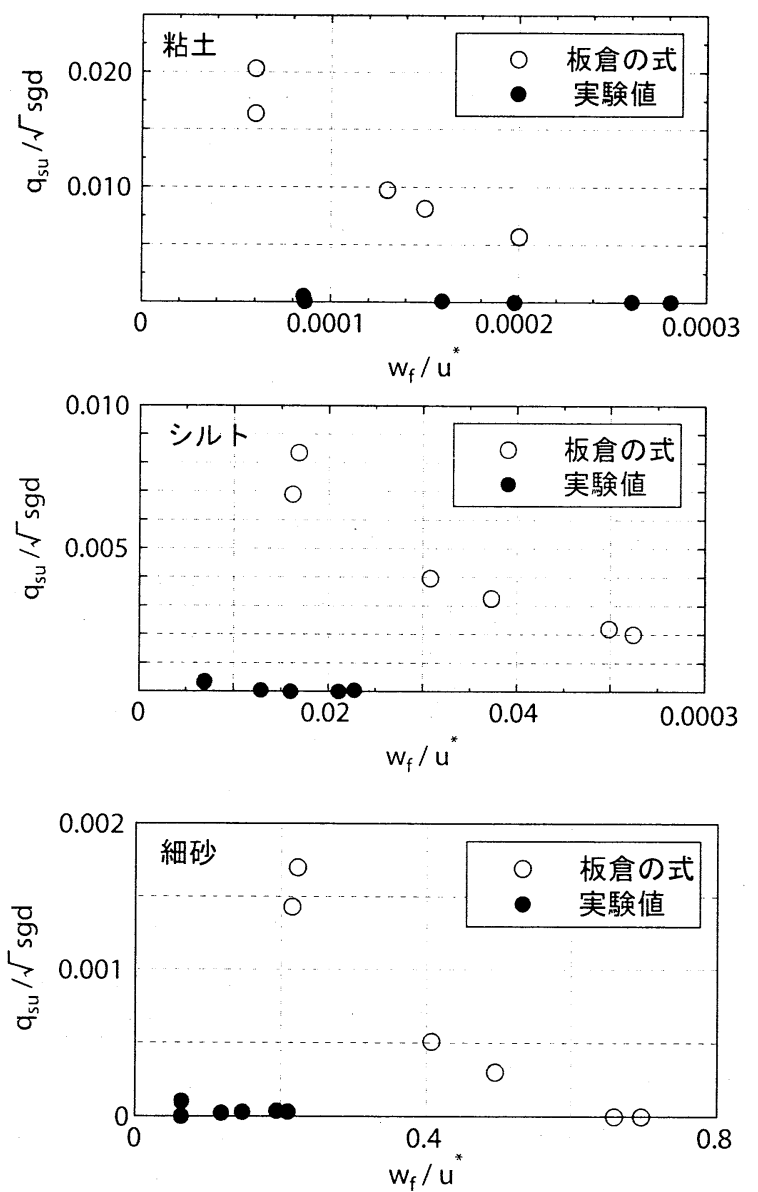

図-7 板倉の式と実験値の浮遊砂比較

こでは実験中河床波等が形成されなかったことから，河 床波等がない場合として全抵抗に等しいとした.これ らの結果をプロットしたものが図-7である，すべての 粒径において板倉の式による結果に比べると浮上量が 小さい傾向が確認された。この結果を受けて, 二風谷 ダム湖内に堆積した土砂の浮上量式を導くことにする. 図-7 の実験值を用いて (4) 式の係数 $K$ について最小二 乗法により $K$ を算出する. その結果，板倉の式におい て従来の係数 $K=0.008$ に対して, 二風谷ダムでの係数 は $K=0.0001$ となり, この係数を用いた浮上量の計算 值と実験值を比較すると図-8 となる。この結果より本 来であれば粘着性土砂について考慮すべきところを板 倉の式の係数 $K$ を変えることにより粒径の非常に細か いもについて再現可能であると考えられる. よって次 節での二風谷ダム湖内における浮上量の算出について はこの係数を用いて行うこととする.

\section{3. ダム湖内の土砂移動計算への適用}

前節で導き出された沈降速度と浮上量の推定式が実 現象に適合するかを確認するため 2003 年 8 月に生起し
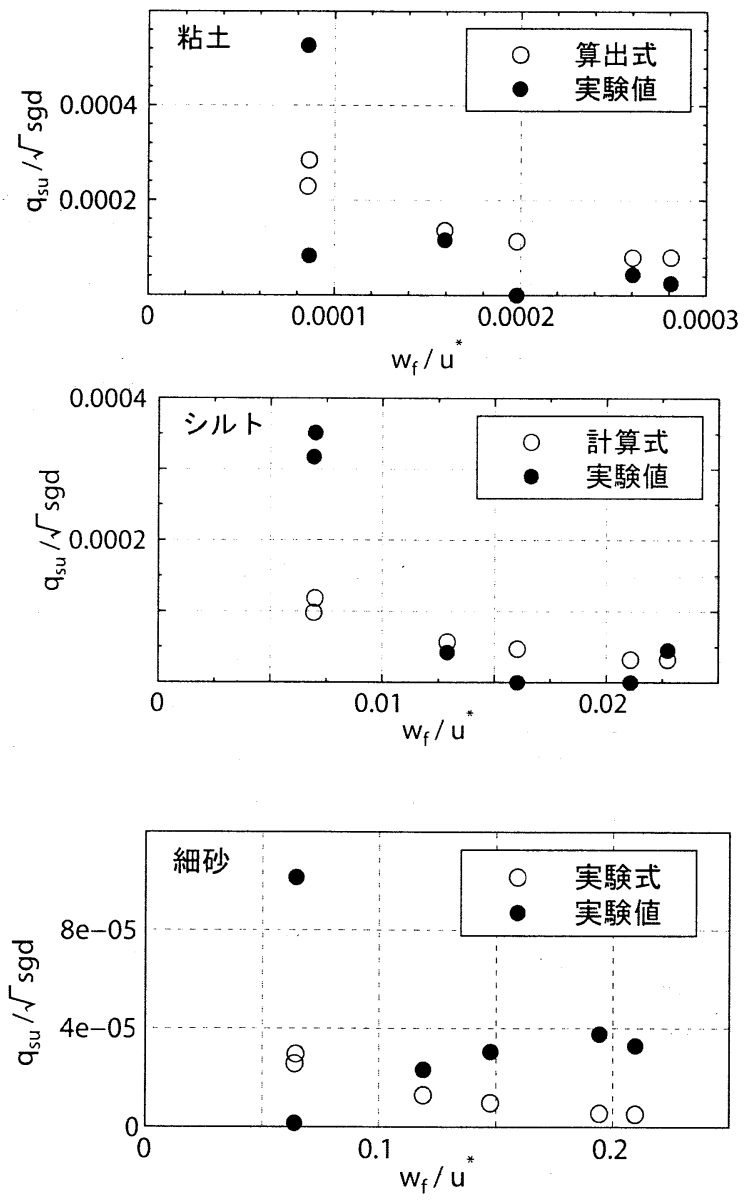

図-8 著者が提案する実験式と実験值の浮遊砂の比較

た沙流川洪水の二風谷ダム湖内の土砂移動の再現を試 みる.この洪水は 2003 年 8 月 9 日深夜から未明にかけ て, 台風 10 号の接近に伴う豪雨により洪水ピーク時の 水位が計画高水位を上回った既往最大の洪水である.

本来であれば少なくとも鉛直 2 次元で計算を行うべ きであるが, 今回は推定式の適合を確認するものであ り簡単のため粒径別 1 次元準非定常流河床変動計算と した.

\section{(1) モデルの概要}

河床変動計算は, 浮遊物質の挙動を見ることから, 掃 流砂と浮遊砂について考慮する事とした.

掃流砂量は粒径別の芦田・道上7)の (8) 式を用いる.

$$
\frac{q_{b i}}{\sqrt{s g d_{i}^{3}}}=p_{i} 17 \tau_{* i}^{\prime \frac{3}{2}}\left(1-\frac{\tau_{* c i}}{\tau_{* i}}\right)\left(1-\frac{u_{* c i}}{u_{*}}\right)
$$

ここで, $u_{* c i}$ : 粒径別限界摩擦速度であって Egiazaroff が 提案した式を利用した浅田 ${ }^{8)}$ の (9) 式で与えれらる.

$$
\frac{u_{* c i}^{2}}{u_{* c m}^{2}}=\left(\frac{\log 23}{\log \left(21 \frac{d_{i}}{d_{m}}+2\right)}\right)^{2} \frac{d_{i}}{d_{m}}
$$




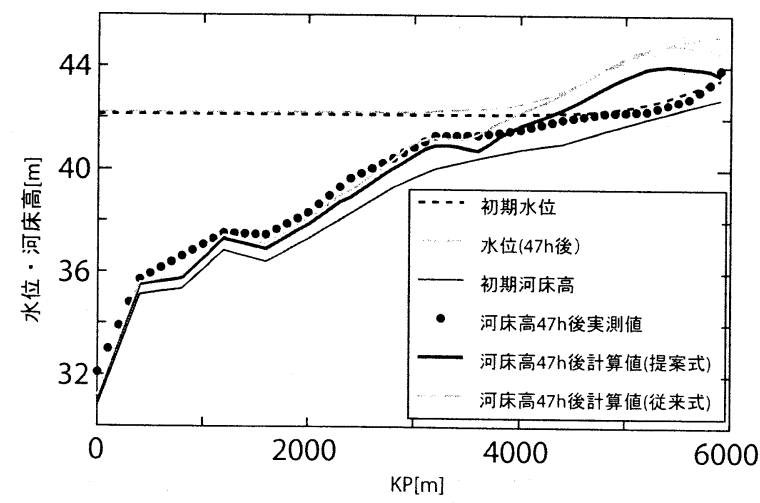

図-9 河床変動計算結果

ここで, $d_{m}$ : 河床材料の平均粒径 $\left(d_{m}=\Sigma d_{i} p_{i}\right), u_{* c m}: d_{m}$ に対する限界摩擦速度であり岩垣の式を用いた.

また浮遊砂量の計算については前述の (4) 式を用い る. ただし係数 $K$ は $K=0.0001$ を, 沈降速度式につい ても (2) 式を用いて計算を行った.

以上より (11) 式で表される全流砂の連続式により河 床変動量を計算する。

$$
\begin{gathered}
\frac{\partial z}{\partial t}+\frac{\Psi}{1-\lambda}=0 \\
\Psi=\frac{1}{B} \frac{\partial \sum_{i}\left(q_{b i} B\right)}{\partial x}+\sum_{i}\left(q_{s u i}-n w_{f i} c_{b i}\right)
\end{gathered}
$$

ここで, $z$ : 河床高, $\lambda$ :河床材料の空隙率, $B: 川$ 川幅, $c_{b i}$ : 河 床付近の粒径別浮遊砂濃度であって (11) 式で表される.

$$
\frac{\partial}{\partial t}\left(\left\langle c_{i}\right\rangle h\right)+\frac{1}{B} \frac{\partial\left(Q\left\langle c_{i}\right\rangle\right)}{\partial x}=q_{s u i}-n w_{f i} c_{b i}
$$

ここで, $\left\langle c_{i}\right\rangle$ :水深平均の粒径別浮遊砂濃度であり, (12) 式で表される.

$$
\left\langle c_{i}\right\rangle=\frac{c_{b i}}{\beta}\{1-\exp (-\beta)\}
$$

ここで, $\beta=\frac{n w_{f i} h}{\epsilon}, \epsilon=\frac{\kappa u_{*} h}{6}, \kappa:$ カルン定数である. さらに粒径別の流砂の連続式は (13) 式で表される.

$$
\delta \frac{\partial p_{i}}{\partial t}+p_{i}^{*} \frac{\partial \eta}{\partial t}+\frac{\Psi}{1-\lambda}=0
$$

ここで， $\delta$ :交換層の厚さ, $p_{i}^{*}$ は $(14)$ 式で表される.

$$
\begin{cases}p_{i}^{*}=p_{i} & : \frac{\partial \eta}{\partial t} \geq 0 \\ p_{i}^{*}=p_{i 0} & : \frac{\partial \eta}{\partial t}<0\end{cases}
$$

ここで, $p_{i 0}$ :粒径 $d_{i}$ の粒子が元河床にしめる割合である.

\section{（2）計算条件と計算結果}

計算に使用したデータは, 2003 年 8 月に沙流川で発 生した洪水である.ダム流入ピーク流量は $6,000 \mathrm{~m}^{3} / \mathrm{sec}$

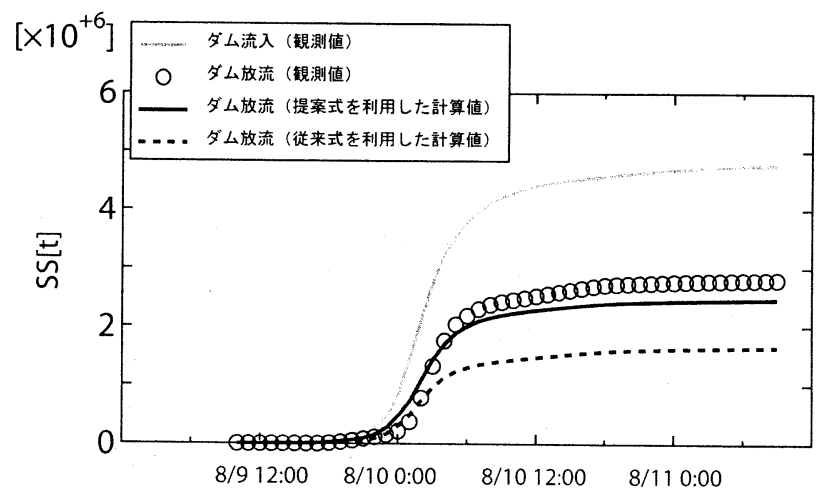

図-10 SS 累計量の比較

表-4 堆砂量の比較

\begin{tabular}{|c|c|c|}
\hline & 堆砂量 $\left[\mathrm{m}^{3}\right]$ & $\mathrm{SS}$ 量 $[\mathrm{t}]$ \\
\hline 横断測量結果 & $2,355,000$ & $2,023,000$ \\
\hline $\mathrm{SS}$ 観測值による収支 & $2,285,000$ & $1,963,000$ \\
\hline 計算結果 (提案式) & $2,421,000$ & $2,299,000$ \\
\hline 計算結果 (従来式) & $3,509,000$ & $3,119,000$ \\
\hline
\end{tabular}

程度である．計算の範囲はダムサイトから貯水池上流 端に位置する貯砂ダム直下までである．計算に用いた河 道断面は 2003 年 6 月に実施されている横断測量のデー タを基に河床高と川幅を決定している.

準非定常流計算条件として, 上流端では洪水期間中 に観測されたダム流入量を一時間毎に一定として与え, 下流端ではダムサイトで観測した水位を与えている.

また河床変動計算に用いた初期条件として上流端浮 遊砂濃度は観測した粒径別の SS データを, 初期河床材 料の粒径分布として 2003 年 7 月に観測したデータを用 いている. なお SS データにはウォッシュロードが含ま れていると考えられるが, 小川ら光による SS 観測值を 用いた収支と実際の堆砂量がほぼ同值という結果から， 今回は粒径別の全 SS データを浮遊砂濃度として利用 した.

河床変動計算を行った結果が図-9 である. 横断測量 の結果と比較すると上流部により多く堆積する結果と なった. 表-4 は堆砂量を示したものであり，これにつ いてはよく再現できていると言える．参考に小川ら33)が 算出した SS 観測值と補完值から算出した累計流入・放 流 SS 量の差 (図-10)より湖内の堆砂量を求めた結果 (SS 観測值による収支) ‡あわせて示しておく。また従 来の板倉の式 (係数 $K=0.008$ ) を使用した結果もあわせ て示しているがこの結果については堆砂の位置・量と もに大きく違いが見られ，今回の推定式がより実現象 を説明していると考えれらる.

また図-11 はオリフィスから放流された SS 濃度を比 較したものである. シルト, 細砂, 全粒径については挙 

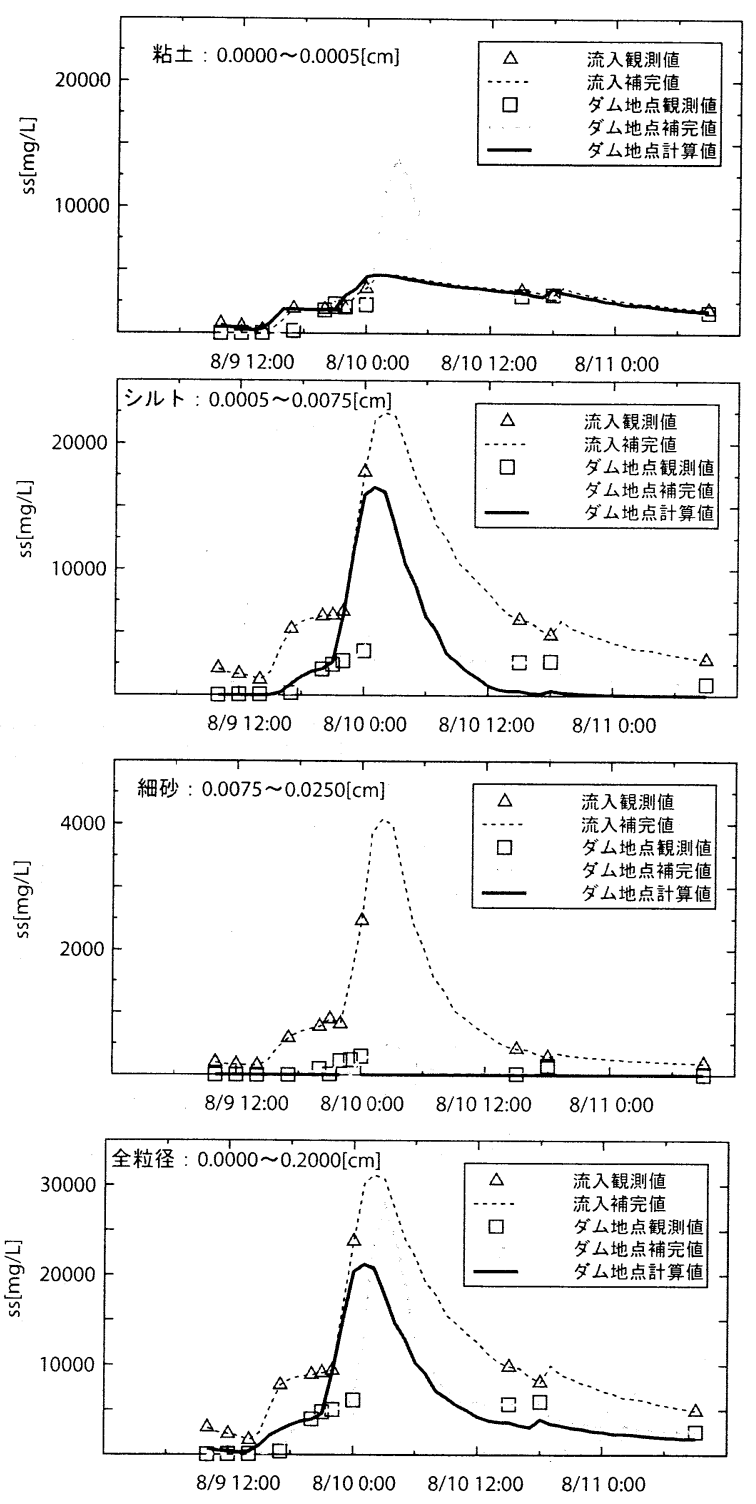

図-11 SS 放流の比較

動が近いと言えるが粘土については相違が見られる.

図-12 は湖底の粒径別区分であるが，実際の観測デー タと計算結果を比較すると, 縦断図の比較結果と同様 に上流部に打いて違いがみられる。

\section{4. おわりに}

本報告はダム湖内における土粒子の挙動を明らかに するため, ダム湖から採取した試料を用いて実験を行 い, その結果を受けて実際の洪水での現象再現を試み た. 計算結果と実現象を比べると堆積量は再現できた が, 特に上流部での堆積位置, 堆積物の粒径について 違いがみられた. またダムからの放流 SSについても違 いが見られたがこれについては観測データ自体がピー クにむけ欠測していたため補完を行っているので単純 な比較は出来ない.これらの課題をうけ, 次のステッ プとしては 1 次元非定常による計算, またダム湖内で

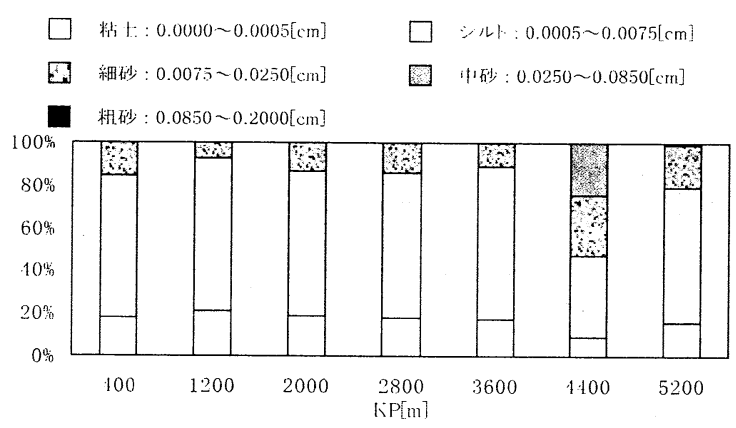

(a) 観測值（7月）

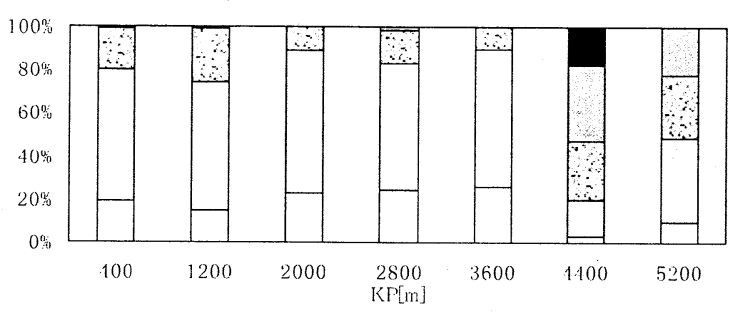

(b) 観測值（9 月）

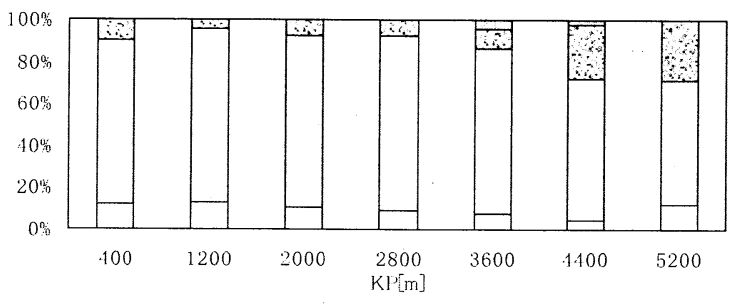

(c) 計算値

図-12 ダム湖底の底質区分

は水深が大きく流速や濃度について水深方向に分布を 持っているものと考えられることから鉛直 2 次元での 計算を行うことでダム湖内における土粒子の挙動を明 らかにし報告する予定である.

\section{参考文献}

1) 渡邊康玄・小川長宏 : 沙流川 2001 年夏季出水時の SS 輸 送特性, 土木学会北海道支部論文, 2002 .

2) 小川長宏・渡邊康玄：中流域にダム湖が存在する河川に おける土砂・物質輸送の観測, 河川技術論文集, vol.9, pp.347-352, 2003.

3) 小川長宏・渡邊康玄: 二風谷ダムでの 2003 年台風 10 号 におけるSS の挙動，河川技術論文集，vol.10，2004

4) Itakura,T.and Kishi, $T$ : Open Channel Flow with Suspended Sediments, Proc.ASCE, Vol.106, No.HY8, pp.1325-1343, 1980.

5）板倉忠興：河川における乱流拡散現象に関する研究, 北 海道開発局土木試験所報告, 第 83 号, 1984 .

6）坊野聡子・清水康行 - 黑木幹男 - 藤田睦博 - 吉田義一： ダムを含む河川の流砂と河床変動に関する研究, 土木学 会論文集, No.656/ -52, pp.61-72, 2000.

7) 芦田和男- 道上正規 : 移動床流れの抵抗と掃流砂量に関 する基礎的研究, 土木学会論文報告集, 第 206 号, 土木 学会, pp.59-69, 1972.

8）浅田宏 : 山地河川の流砂量と貯水池の堆砂過程に関する 研究, 電力中央研究所報告, No.2, 1976 .

(2004. 9.30 受付) 